\title{
ВИДОВИЙ СКЛАД ПАТОГЕННОЇ ТА УМОВНО-ПАТОГЕННОЇ МІКРОФЛОРИ У ХВОРИХ НА ГОСТРІ КИШКОВІ ІНФЕКЦІЇ У ДНІПРОПЕТРОВСЬКОМУ РЕГІОНІ
}

\author{
Дніпропетровська медична академія
}

За даними бактеріологічних досліджень, показано склад патогенних ентеробактерій та умовнопатогенної мікрофрлори у хворих на гострі кишкові інфрекції, які проходили стаціонарне лікування в умовах інфрекційної лікарні м. Дніпропетровськ у 2013-2014 рр. Вивчено спектр чутливості сальмонел до «класичних кишкових» антибіотиків. Сальмонели виявили чутливість до цефртриаксону, цефротаксиму, цефртазидиму, ципроорлоксацину та були стійкі до гентаміцину, доксицикліну та левоміцетину. Результати дослідження сприятимуть уявленню про розповсюдженість збудників гострих кишкових інфекцій у сучасних умовах та допоможуть практичному лікареві у призначенні емпіричної терапії хворим на гострі кишкові інфекціі або із синдромом гострого гастроентероколіту до отримання результатів лабораторних досліджень у своїх пацієнтів.

Ключові слова: гострі кишкові інфрекції, мікробний пейзаж, сальмонели, шигели, ешерихії, умовнопатогенна мікрофрлора.

Гострі кишкові інфекції (ГКІ) становлять велику медичну проблему, що пов'язано з високою захворюваністю серед населення у всіх вікових групах. На сьогодні в структурі інфрекційних захворювань вони поступаються лише гострим респіраторним вірусним інорекціям [1]. Ризик розвитку хвороб, пов'язаних із вживанням їжі, напоїв, води, що контаміновані різноманітними бактеріями, вірусами та іншими мікроорганізмами, для країн з помірним кліматом зростає у літньо-осінню пору, а в країнах з тропічним кліматом вони реєструються цілорічно [2]. ВООЗ намагається постійно звернути увагу на цю проблему, навіть Всесвітній день здоров'я, який щороку відзначається 7 квітня та проходить під різними гаслами, у 2015 р. був присвячений безпеці харчових продуктів.

Виявлення збудника та визначення його ролі в етіологічному тлумаченні інфекційного захворювання має велике епідеміологічне значення, дозволяє про- стежити шляхи розповсюдження інфекції, оптимізувати терапію та заходи її профрілактики [3, 4]. Останнім часом у нашій країні зростає захворюваність на ГКІ, що викликані умовно-патогенними мікроорганізмами, а патогенні ентеробактерії поступово здають свої позиції [5-7].

На сучасному етапі в Україні встановити етіологічний фрактор ГКІ вдається не завжди (у 56-80\% хворих). Видовий пейзаж фекальної фрлори при ГКІ $€$ дуже різноманітним та оскільки мікрофрлора дуже динамічна, картина його з роком змінюється [5]. При інфекційних діареях достовірний діагноз неможливий без лабораторного підтвердження у зв'язку з поліетіологічністю ГКІ на фоні аналогічних клінічних проявів [8]. Нераціональна антибіотикотерапія ГКІ призводить до формування резистентних штамів патогенних та умовно-патогенних мікроорганізмів, що у подальшому потребує пошуку інших ефрективних засобів лікування хворих $[9,10]$.

Мета роботи - вивчити мікробний пейзаж у хворих на ГКІ та харчові токсикоінфекції в сучасних умовах для підвищення ефективності лікування та епідеміологічного контролю.

\section{Пацієнти і методи}

Нами було досліджено мікробний пейзаж у дорослих пацієнтів та дітей з ГКІ і харчовими токсикоінсеекціями (XTI), які знаходилися на стаціонарному лікуванні в КЗ «Міська клінічна лікарня № 21 ім. профр. Є.Г. Попкової» (інфрекційна лікарня) м. Дніпропетровська за період 2013-2014 рр. Діагноз встановлювали на підставі сукупності клінічних та епідеміологічних даних, результатів бактеріологічного дослідження, серологічних реакцій (РНГА), імуноферментного аналізу та імунохроматограсрії. Більшість випадків захворювань перебігали за класичним варіантом гастроінтестинального синдрому, а саме з синдромами гострого гастриту, гастроентериту, гастроентероколіту (ГЕК) та коліту.

Для досліджень мікробного пейзажу відбирали проби випорожнень на відповідні поживні середовища за кла- 
сичними методиками. При обстеженні на кишкову групу інфекцій вивчали частоту виділення з випорожнень та етіологічний розподіл патогенної та умовно-патогенної мікрофрлори. Також, за необхідністю, досліджували спектр мікрофрлори блювотиння, промивних вод шлунку або крові. Антибіотикограми (чутливі або резистентні штами) вивчали тільки у хворих з патогенною фрлорою, а саме у хворих на сальмонельоз.

В клінічному перебігу зберігались основні «класичні» клінічні ознаки, спостерігається лише сприятливий перебіг хвороби, відсутні генералізовані форми. Хворі отримували регідратаційну терапію (оральну і парентеральну), ентеросорбенти, кишкові антисептики. Антибіотикотерапія призначалась парентерально в тяжких випадках.
Всього досліджено: у 2013 р. 1917 зразків патологічного біологічного матеріалу, у 2014 р. - 1865. Результати клінічного спостереження та проведених досліджень були піддані статистичній обробці з використанням програми Statistica 7.

\section{Результати досліджень та їх обговорення}

У 2014 р. в інфекційній лікарні проліковано 1398 хворих на ГКІ, що на 8,7 \% менше, ніж у 2013 р. Середній ліжко-день становив $(11,0 \pm 1,04)$ діб. У всіх пацієнтів захворювання закінчилося видужанням.

Пік госпіталізації хворих мав загальні тенденції та спостерігався з червня по жовтень, що пов'язано із сезонним підвищенням захворюваності на ГКІ (мал. 1).

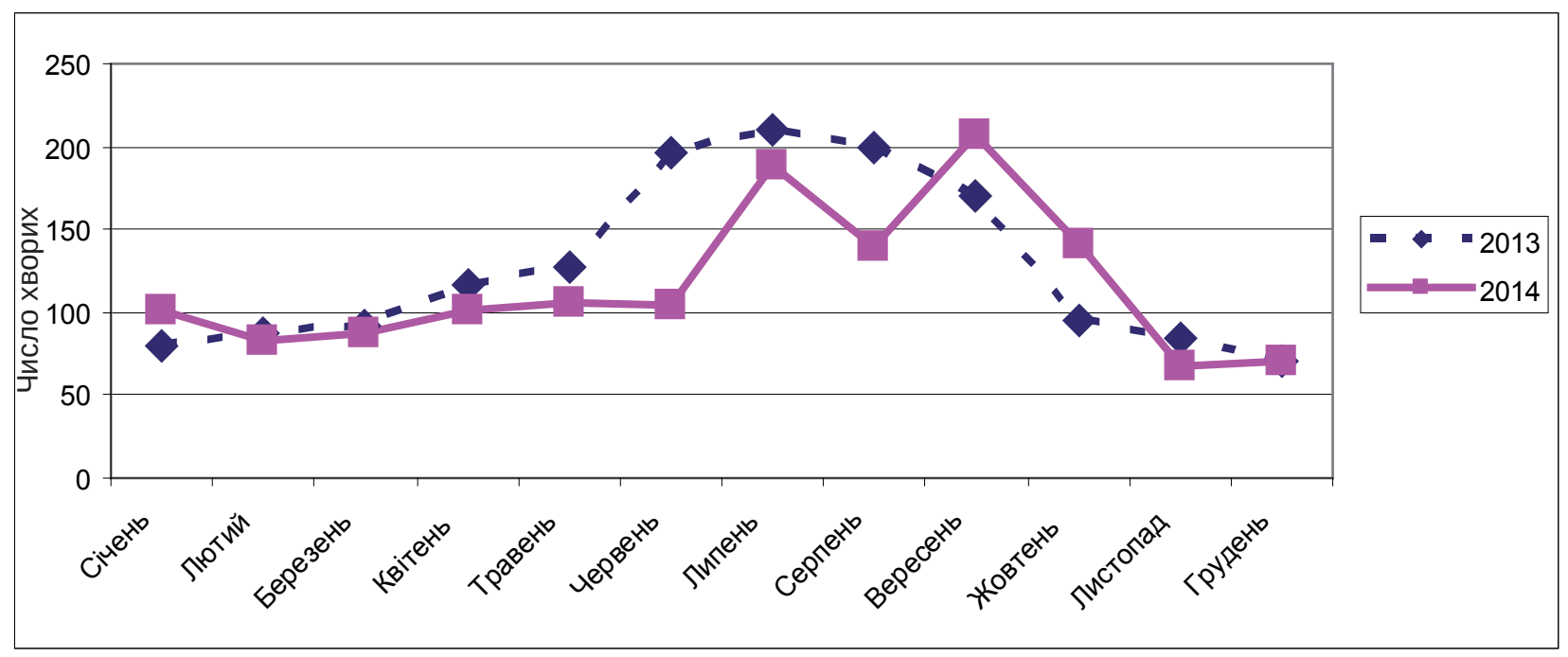

Мал. 1. Помісячна динаміка реєстрації випадків ГКІ у порівнянні за 2 роки (абс. пок.).

Спектр нозологічних одиниць у хворих на ГКІ представлений у таблиці 1. Серед нозологічних одиниць відмічається невисокий рівень захворювань, викликаних патогенними ентеробактеріями (шигели, сальмонели, ешерихії). Більша частка випадків ГKI припадає на гострі гастроентерити, гастроентероколіти та коліти.

Таблиця 1

Спектр нозологічних одиниць у хворих на ГКІ (абс. пок.)

\begin{tabular}{|l|c|c|c|c|}
\hline \multirow{2}{*}{ Нозологія } & \multicolumn{2}{|c|}{2013} & \multicolumn{2}{c|}{2014} \\
\cline { 2 - 5 } & У дорослих & У дітей & У дорослих & У дітей \\
\hline ГЕК встановленої етіології & 669 & 109 & 808 & 129 \\
\hline ГЕК не визначеної етіології & 355 & 88 & 181 & 111 \\
\hline ХТІ встановленої етіології & 52 & 8 & 19 & 2 \\
\hline ХТІ не визначеної етіології & 45 & 10 & 17 & 4 \\
\hline Сальмонельоз & 157 & 13 & 6 & 9 \\
\hline Шигельоз & 8 & 2 & 2 & 0 \\
\hline Ешерихіоз & 10 & 2 & 0 & 0 \\
\hline Ротавірусна інсрекція & 2 & 1 & 1142 & 1 \\
\hline Всього & 1298 & 233 & & 256 \\
\hline
\end{tabular}




\section{ОРИГІНАЛЬНІ ДОСЛІДЖЕННЯ}

Також у 2014 р. відзначається зниження рівня захворюваності на сальмонельоз порівняно з 2013 р. на 30,6 \% за рахунок дорослого контингенту населення. Зросла питома частка гастроентероколітів, спричинених умовно-патогенними мікроорганізмами, в структурі ГКІ на 8 \%. Причому питома частка етіологічної розшифрровки ГЕКів зберігається на достатньо високому рівні, а саме 86 \%, як і у 2013 р. Етіологічна розшифровка ХTI становить 63 \% (у 2013 р. - 56 \%). Верисрікація ГКІ вірусної етіології класичними методами не проводиться через високу вартість та трудоємність досліджень, тільки за допомогою швидких тестів в окремих випадках (методом імунохроматографрії). Усі випадки остаточного діагнозу шигельоз або сальмонельоз були встановлені на підставі бактеріологічного підтвердження діагнозу.

При подальшому вивченні мікробного пейзажу у хворих на ГКІ виявлено, що найчастіше серед групи патогенних ентеробактерій були виділені сальмонели, серед яких найбільша частка - сальмонели групи D. Як видно з малюнку 2, за два роки дослідження стабільно переважають сальмонели групи D - S. enteritidis. Принаймні, також при проведенні досліджень було виявлено і рідкісні для нашого регіону варіанти сальмонел, а саме S. dublin, S. newport, S. saintpaul, S. potsdam.

У групі дітей віком молодше 18 років, хворих на сальмонельоз, етіологічним чинником була тільки S. enteritidis. За тяжкістю перебігу як серед дітей, так і серед дорослих переважали форми з середнім ступенем тяжкості - 69,5\%, тяжкі форми - 30,5 \%, легких випадків на стаціонарному лікуванні не було. Слід зазначити, що найпоширенішим епідеміологічним фрактором захворювання на сальмонельоз у пацієнтів було вживання сирих яєць.

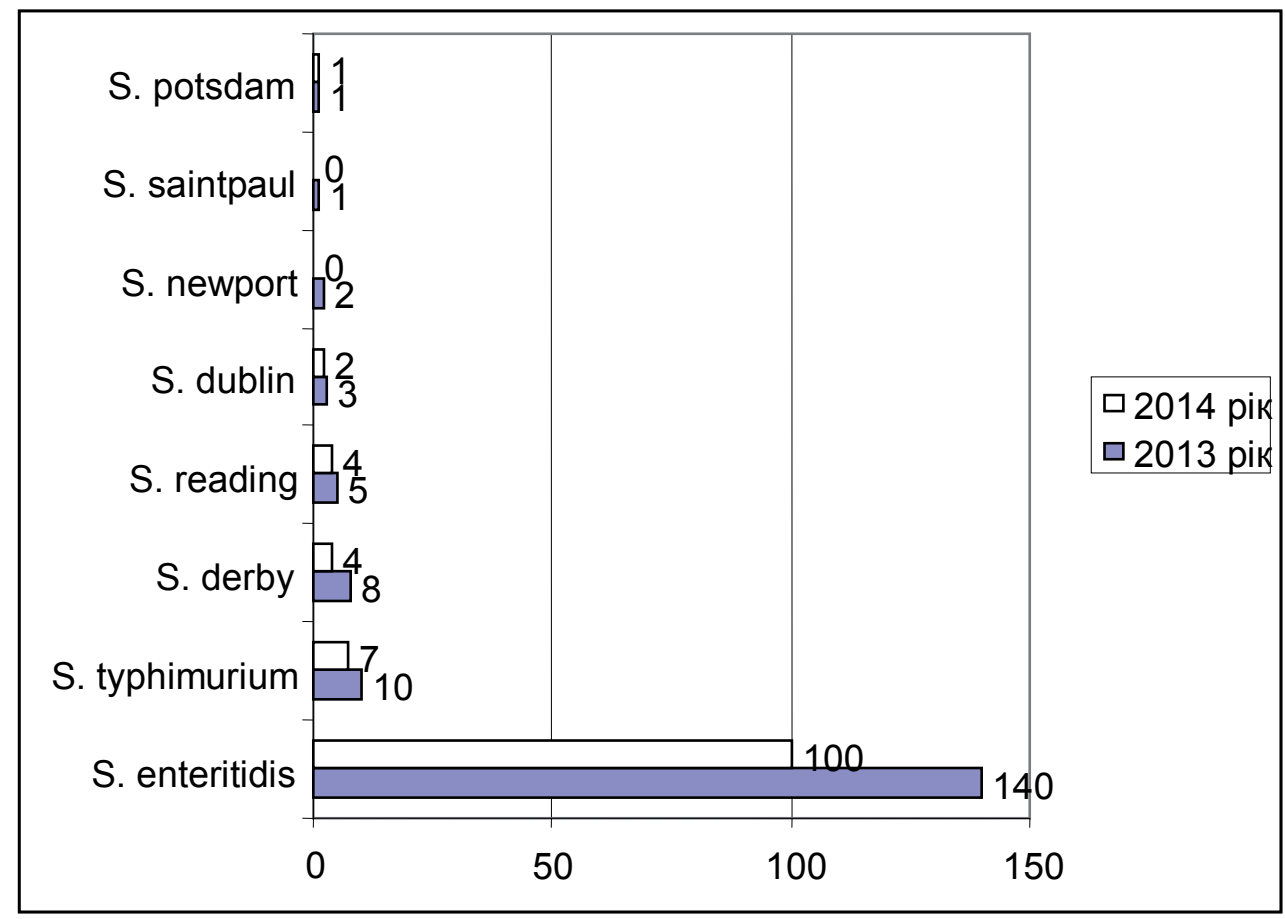

Мал. 2. Пейзаж видового складу сальмонел у хворих на ГКІ порівняно за 2013 і 2014 рр. (абсолютні показники).

Рівень захворюваності на шигельоз з кожним роком знижується (табл. 1). Так, у 2013 р. виявлено 10 випадків проти 6 у 2014 р. У всіх випадках етіологічним чинником була S. flexneri.

Також спостерігається зниження захворюваності на ешерихіоз. У 2013 р. проліковано 12 хворих, у 2014 р. зареєстровано 2 випадки. Етіологічне підтвердження - в 100 \% випадків виділена E. coli O-01.

Виявлена низька кількість позитивних результатів досліджень проб промивних вод шлунка при XTI, це може свідчити про те, що значна частина населення починає етіотропне лікування вдома або амбулаторно. Хворі звертаються за медичною допомогою тільки при появі загально тяжких ознак хвороби та після невдалих спроб самолікування. Наслідком цього є зниження результативності діагностичних досліджень та ускладнення проведення епіднагляду.

На малюнку 3 представлені дані пейзажу умовнопатогенної фрлори, які виступили етіологічним чинником ГKI та XTI, за нашими даними, у період з 2013 по 


\section{ОРИГІНАЛЬНІ ДОСЛІДЖЕННЯ}

2014 рр., і які є резидентними представниками нормальної фрекальної фрлори людини. Причому, виділені культури мали вміст мікроорганізмів >106 KУО/г.

Виділена умовно-патогенна мікрофлора представлена широким спектром різновидів ентеробактерій та грибів і становить переважну частину фракультативних анаеробів фрекальної фрлори. Найчастіше при кишкових інфекціях, спричинених умовно-патогенними мікроорганізмами, виділялись бактерії родини Klebsiella, Enterobacter та Citrobacter. А саме, їх найяскравіші представники Klebsiella pneumoniae, Enterobacter cloacae та Citrobacter freundii. Не здає своїх позицій умовнопатогенна мікрофрлора - рід Staphylococcus та Proteus, гриби рода Candida.

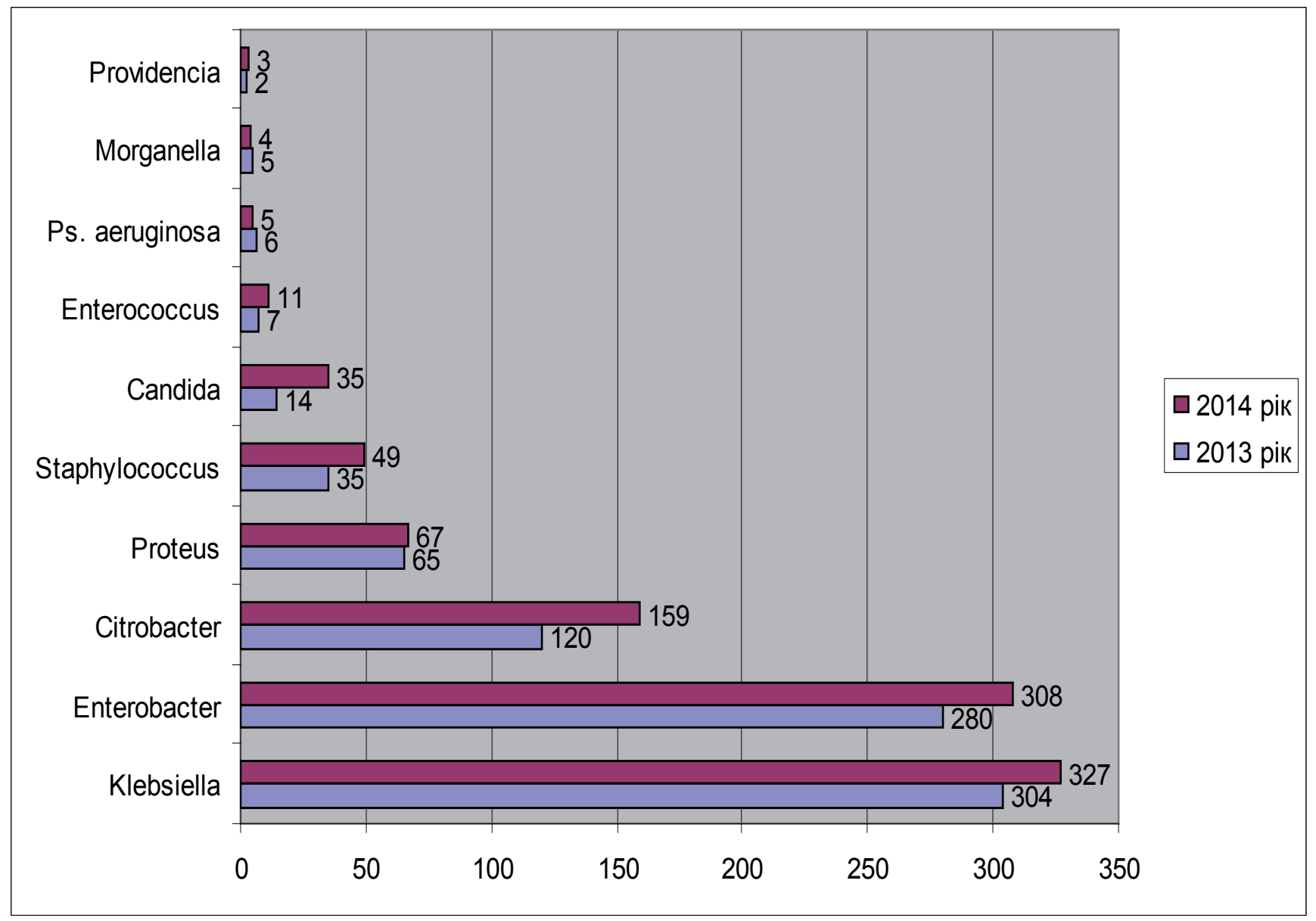

Мал. 3. Пейзаж видового складу умовно-патогенної мікрофрлори у хворих на ГКІ порівняно за 2013-2014 роки (абсолютні показники).

При дослідженні чутливості сальмонел до антибіотиків (антибіотикограми) - виявлена чутливість (S) у різній мірі до цефртриаксону, цефотаксиму, цефтазидиму, ципрофлоксацину. Сальмонели проявляли стійкість (резистентність - R) до гентаміцину, доксицикліну та левоміцетину.

Таким чином, результати бактеріологічних лабораторних досліджень $є$ важливими для призначення адекватної терапії, епідеміологічного нагляду та прогнозування розповсюдження кишкових інфекцій.

\section{Висновки}

1. ГКІ залишаються однією з важливих проблем інфектології. При бактеріологічному дослідженні біологічного матеріалу серед етіологічних чинників гастроінтестинального синдрому у хворих спостерігається широкий спектр умовно-патогенної фрлори, а саме Klebsiella, Enterobacter та Citrobacter.

2. Серед патогенних ентеробактерій не втрачає своєї актуальності сальмонельоз, хоч захворюваність дещо знизилась. У представленому пейзажі виділених саль- 
монел за два роки дослідження стабільно переважають сальмонели групи D - S. enteritidis. Почали зустрічатися рідкісні для нашого регіону варіанти сальмонел. Серед шигел виділяється S. flexneri.

3. У клінічному перебігу зберігаються основні «класичні» клінічні ознаки ГКІ, спостерігається лише сприятливий перебіг хвороби, відсутні генералізовані форми. При вивченні антибіотикограми у патогенних ентеробактерій, насамперед сальмонел, виявлена чутливість до «класичних кишкових» антибіотиків, а саме до цестриаксону, цеоротаксиму, цефтазидиму, ципрофлоксацину. Сальмонели були стійкі до гентаміцину, доксицикліну та левоміцетину.

4. Виявлений спектр чутливості може бути корисним лікарю при призначенні емпіричної терапії гострих кишкових інорекцій, а саме сальмонельозу - до отримання результатів лабораторних досліджень у своїх пацієнтів в нашому регіоні, враховуючи близькі властивості циркулюючих штамів патогенних ентеробактерій на одній території.

\section{Література}

1. Козько В.М. Мікробіоценотичні аспекти гострих кишкових інсекцій / В.М. Козько, А.В. Бондаренко // Інфеецційні хвороби. 2007. - № 2. - С. 5-11.

2. Малый В.П. Общая характеристика острых кишечных инфекций / В.П. Малый // Клінічна імунологія. Алергологія. Інфектологія. - 2010. - № 4. - С. 14-30.

3. Васильєва Н.А. Диференційна діагностика хвороб 3 гострим діарейним синдромом / Н.А. Васильєва, Б.А. Локай // Інфекційні хвороби. - 2006. - № 1. - С. 58-66.

4. Small intestinal bacterial overgrowth syndrome / [J. Bures, J. Cyrany, D. Kohoutova et al.] // World J. Gastroenterol. - 2010. Vol. 16, N 24. - P. 2978-2990.

5. Пейзаж патогенних ентеробактерій та умовно-патогенної мікрофрлори у хворих на гострі кишкові інфрекції в сучасних умовах / Л.Р. Шостакович-Корецька, О.П. Шевченко, К.Ю. Литвин, О.Л. Чемерис // Проблеми військової охорони здоров'я України: зб. наук. пр. - К.: УВМА, 2013. - Вип. 39. - С. 398-403.

6. Андрейчин М.А. Шигельоз / М.А. Андрейчин, В.М. Козько, В.С. Копча. - Тернопіль: Укрмедкнига, 2002. - 362 с.

7. Возианова Ж.И. Диареегенные кишечные палочки / Ж.И. Возианова // Сучасні інсекції. - 2008. - № 3. - С. 4-9.
8. Крамарев С.А. Острые кишечные инсрекции у детей: клиника, диагностика, лечение / С.А. Крамарев // Здоров'я України. - 2013. - № 2(28). - C. 46-47.

9. Аналіз антибіотикорезистентності патогенних та умовнопатогенних мікроорганізмів, вилучених від дітей, хворих на гостру кишкову інфекцію / [І.А. Воронкіна, С.А. Деркач, О.В. Коцар та ін.] // Annals of Mechnicov Institute. - 2008. - № 1. - C. 30-37.

10. Чемич М.Д. Застосування комбінованого пробіотика «Лакто» у лікуванні гострих кишкових інсрекцій, викликаних умовнопатогенними мікроорганізмами // М.Д. Чемич, К.С. Полов'ян // Iнформ. лист про нововведення у системі охорони здоров'я. -2012 - № $324-6$ c.

\section{SPECIES COMPOSITION PATHOGENIC AND OPPORTUNISTIC PATHOGENIC MICROFLORA IN PATIENTS WITH ACUTE INTESTINAL INFECTIONS IN DNIPROPETROVSK REGION}

O.P. Shevchenko-Makarenko

SUMMARY. The article presents the structure of pathogenic enterobacteria and opportunistic microflora, according to bacteriological studies, in patients with acute intestinal infections who were hospitalized in Infectious Diseases Hospital of Dnepropetrovsk city in 20132014 years. The spectrum of sensitivity to Salmonella to "classic intestinal" antibiotics is studied. Salmonella species showed sensitivity to ceftriaxone, cefotaxime, ceftazidime, and ciprofloxacin; they were resistant to gentamicin, doxycycline and chloramphenicol. Results of the study will contribute to the prevalence of pathogens presentation of acute intestinal infections under current conditions and will help practitioners in the assigning empirical treatment of patients with acute intestinal infection or syndrome of acute gastroenterocolitis before receiving the laboratory results in their patients.

Key words: acute intestinal infections, microbial landscape, Salmonella, Shigella, Escherichia, opportunistic pathogenic microflora.

Отримано 21.09.2015 p. 